\title{
Inaccurate Information
}

National Cancer Institute

\section{Source}

National Cancer Institute. Inaccurate Information. NCI Thesaurus. Code C133643.

Problem associated with imprecise, inexact information. 